\title{
Volume Contracts and Third Parties: 'Red Hand' Rule or Red Herring?'
}

\section{Introduction}

The UN Convention on Contracts for the International Carriage of Goods Wholly or Partly by Sea, ${ }^{2}$ colloquially known as the Rotterdam Rules, ${ }^{3}$ has been open for signature since September 2009. The launch of the Convention signalled the end of yearly delegations to devise a modern and uniform carriage regime for maritime and multimodal transport. ${ }^{4}$ The RR initiate new entities, concepts ${ }^{5}$ and more contractual options, ${ }^{6}$ compared to the fragmented regime already in force. ${ }^{7}$ The most heralded ones concern the broader multimodal scope of application, ${ }^{8}$ the right of control, ${ }^{9}$ provisions on e-commerce, ${ }^{10}$ and lastly, the possibility to contract out of the RR. The last-mentioned will occur in cases of customised carriage agreements, so- called volume contracts, through derogations. This possibility of derogations has been received with caution. ${ }^{11}$ The provisions of the RR derogating from the Convention have been analysed; ${ }^{12}$ however, the existing bibliography has posed important questions which remain to be answered.

A volume contract may provide for greater or lesser rights and liabilities than those imposed by the RR, for the carrier and/or the shipper. Derogations are agreed by the shipper and carrier in the first place and produce results between them. However, the drafting of the provisions on derogations from the RR is so ambiguous that it makes it difficult to foresee if and how third parties will be bound by such derogations. It is feared that derogations

* Dr. Ioanna Magklasi LLB (Athens), LLM (Soton), PhD (Soton), Attorney-at-Law, Member of the Athens Bar Association Senior Lecturer in Maritime and International Commercial Law Course Director of the Postgraduate Diploma in Maritime Law (PG Dip) and LLM Top Up in Maritime Law School of Law, London Metropolitan University.

1. DOI $10.7590 / 187714615 X 14328875962582$

2. See www.uncitral.org/pdf/english/texts/transport/rotterdam_rules/Rotterdam-Rules-E.pdf, accessed 13 March 2015 . The text of the Convention has been corrected, and approved, see http://treaties.un.org/doc/Publication/CN/2012/CN.563.2012-Eng.pdf, accessed 13 March 2015.

3. This is how the UN Convention on Contracts for the International Carriage of Goods Wholly or Partly by Sea, open for signature in September 2009 is colloquially known. The launch of the RR in September 2009 epitomises an attempt to provide a harmonised carriage regime and a modern alternative to the Hague Visby Rules, the Hague Rules, and the Hamburg Rules ensuring that there is sufficient protection of the carrier, but also of the cargo interests. Hereafter 'the Rules', 'the Convention', or 'RR'.

4. For a thorough analysis see Regina Asariotis, 'Reflections on the Rotterdam Rules', in: M.A. Clarke (ed.), Maritime Law Evolving: Thirty Years at Southampton (Hart Publishing 2013) 131; Regina Asariotis, 'UNCITRAL Draft Convention on Contracts for the Carriage of Goods Wholly or Partly by Sea: Mandatory Rules and Freedom of Contract', in: Antapassis, Athanassiou \& Rosaeg (eds.), Competition and Regulation in Shipping and Shipping Related Industries (Martinus Nijhoff/Kluwer 2009), 347 (hereafter 'UNCITRAL Draft Convention'). See generally, Jose Angelo Estrella Faria, 'Uniform Law for International Transport at UNCITRAL: New Times, New Players, and New Rules' (2009) 44 Texas International Law Journal 303; M.F. Sturley, 'Transport law for the twenty-first century; an introduction to the preparation, philosophy, and potential impact of the Rotterdam Rules' (2008) 14 JIML 461; Theodora Nikaki \& Baris Soyer, 'A New International Regime for Carriage of Goods by Sea: Contemporary, Certain, Inclusive, and Efficient, or Just Another One for the Shelves?' (2012) 30 Berkeley Journal of International Law 303; Michael Sturley, 'General Principles of Transport Law and the Rotterdam Rules, paper in the conference, The Rotterdam Rules appraised', 24-25 September 2009.

5. Richard Williams, 'Transport Documentation under the New Convention' (2008) 14 JIML 566.

6. David Short, 'How far can you dream?', Address at the Texas Int'l Law Journal Symposium, Transport Law for the 21 st century: The new UNCITRAL Convention (on freedom of contract).

7. Namely the Hague Rules, the Hague Visby Rules and the Hamburg Rules. See Francesco Berlingieri, 'A comparative analysis of the Hague-Visby Rules, the Hamburg Rules and the Rotterdam Rules' at www.uncitral.org/pdf/english/workinggroups/wg_3/Berlingieri_paper_comparing_RR_Hamb_HVR.pdf, accessed 13 March 2015.

8. Hannu Honka, 'Scope of application and freedom of contract', at www.rotterdamrules2009.com/cms/uploads/Def.\%20tekst\%20Hannu\%20Honka.pdf, accessed 13 March 2015.

9. Gertjan van Der Ziel, 'Chapter 10 of the Rotterdam Rules: Control of Goods in Transit' (Spring 2009), Vol. 44 Texas International Law Journal 375; Liang Zhao, 'Control of goods carried by sea and practice in e-commerce' (2013) 6 JBL 585; G.J. van der Ziel, 'Delivery of the goods, rights of the controlling party and transfer of rights' (2008) 14(6) JIML 597.

10. Manuel Alba, 'Electronic Commerce Provisions in the UNCITRAL Convention on Contracts for the International Carriage of Goods Wholly or Partly by Sea' (Spring 2009) 44 Texas International Law Journal 387; Nicholas Gaskell, 'Bills of lading in an electronic age' (2010) LMCLQ 233; Miriam Goldby, 'The CMI rules for electronic bills of lading reassessed in the light of current practices' (2008) LMCLQ 56; Miriam Goldby, 'The performance of the bill of lading's functions under UNCITRAL's Draft Convention on the Carriage of Goods: unequivocal legal recognition of electronic equivalents' (2007) JIML 160.

11. See 'Australian comments on the UNCITRAL Draft Convention on Contracts for the International Carriage of Goods wholly or partly by Sea' (2008) 22 AENZ Mar LJ 123, 124; CLECAT Position paper at www.uncitral.org/pdf/english/texts/transport/rotterdam_rules/CLECATpaper.pdf, accessed 13 March 2015.

12. On volume contracts generally see Asariotis, 'Reflections on the Rotterdam Rules', 152-161; and Asariotis, 'UNCITRAL Draft Convention', 356-364; Mankowski, 'The Rotterdam Rules-Scope of Application and Freedom of contract' (2010) 1/2 EJCCL 9; Basu Bal \& P. Mukherjee, 'A Legal and Economic Analysis of the Volume Contract Concept under the Rotterdam Rules: Selected Issues in Perspective' (2009) 40.4 JMLC 579; Basu Bal \& P. Mukherjee, 'The Impact of the Volume Contract Concept on the Global Community of Shippers: The Rotterdam Rules in Perspective' (2010) JIML 16 352; Lars Gorton, 'Volume Contracts of Affreightment: Some Features and Principles', 
will be abused by large carriers to the detriment of small, medium-sized shippers and third parties.

This article will discuss articles 1(2), 80(2) and 80(5) of the RR and highlight the potential which is left for their interpretation. First, the concept of volume contracts will be introduced.

\section{Volume contracts: Definition and background}

Volume contracts are recognised as contracts of carriage to which the RR apply by default. This means contracts providing for the carriage of a specified quantity of goods in a series of shipments during an agreed period of time. ${ }^{13}$ The Convention does not impose any specifications of quantity (minimum, maximum or a certain range) for a contract to be classified as a volume contract. ${ }^{14}$ Article 80 sets the prerequisites under which a volume contract, which would otherwise be subject to the RR, may entirely or partly derogate from the Convention. However, the way volume contracts and derogations are permitted by the $\mathrm{RR}$ is contentious and gives rise to uncertainties. ${ }^{15}$

The concept of contracting out of the mandatory scope of the RR is not ipso facto objectionable or dangerous when parties stand on an equal footing. Volume contracts with derogations is an innovative concept of the RR, which however had to be drafted in a way that reserves this contractual freedom to the parties of a balanced negotiating and market power. With major associations already drafting their standard volume contracts, ${ }^{16}$ it is indispensable that any ambiguities deriving from the (de)regulation of volume contracts are addressed before it is too late. This author aims to offer interpretational help to the obligations prescribed by article 80(5) of the Rotterdam Rules and additional contractual solutions which allow the article to have the impact that the draftsmen of the Convention originally intended.

The primary observation that one would make on the framework that the RR establish for volume contracts is the lack of a specification that they should only apply between parties of equal bargaining power.

If abuse of the derogations from the RR is possible for the original parties to volume contracts, this prepares us for the vulnerability that lurks for third parties, who are outside the negotiation context. A third party/buyer waiting for his goods overseas will have to check not only the transport document, but also the carriage contract information indicating the derogations. This is an even weightier issue, if one considers that the RR may apply irrespective of whether or not a transport document is issued. ${ }^{17}$

According to article $80(5)$ of the RR, a third party is bound by a volume contract if he has provided his express consent to the derogations. As shall be seen, the requested consent may be pre-contractual or post-contractual, ${ }^{18}$ according to the time the sale contract was entered into, and its specification on what the carriage contract should entail.

Analyses of renowned academics on the formalities of providing information and requesting consent for volume contract derogations are not perfectly consistent with each other. The same inconsistencies exist in how a volume contract can be recognised. The analysis that follows will diminish the vagueness of article 80(5) of the $\mathrm{RR}$ and will identify whether each derogation shall be communicated individually, or whether the general notification of a derogated volume contract is sufficient. Furthermore, it will ascertain whether the derogations initiating exemption from liability have to be specifically addressed to the third party, or whether the general knowledge of derogations means that the third party on his own should discover them. In other words, this author will investigate what the information received should contain, and ultimately what the court is to decide when an onerous or unreasonable derogation is proven to have fallen outside the parties' awareness.

\section{Article 80(5): Third parties bound by a volume contract}

As far as parties other than the shipper and carrier are concerned, article 80(5)(a) of the RR applies: this holds a party bound by the terms of the volume contract, if that party has received information prominently stating that the volume contract derogates from the Convention and has expressed his consent to these derogations. This consent must be given as prescribed by article 3 of the $\mathrm{RR}$, i.e. in writing, or through electronic communication. The intricacy of this provision derives from its inconsistent wording. On the one hand, there is a general requirement that the third party is notified that the contract merely derogates from the RR. On the other, the third party has to expressly consent to be bound by such derogations.

The article is not clear on whether the third party needs to be notified of the fact that there is a derogation in

at www.scandinavianlaw.se/pdf/46-3.pdf, accessed 13 March 2015; Filippo Lorenzon, 'Validity of contractual terms', in: Baatz, Debattista, Lorenzon, Serdy, Staniland \& Tsimplis, The Rotterdam Rules: A Practical Annotation (Informa 2009), paras 80-01-80-11; Fujita, Sturley \& Van der Ziel, The Rotterdam Rules (Sweet \& Maxwell 2010); Hannu Honka, 'Validity of contractual terms', in: Von Ziegler, Schelin \& Zunarelli (eds.), The Rotterdam Rules 2008 (Kluwer 2010) 331-348; Meltem Deniz Güner-Özbek (ed.), The United Nations Convention on Contracts for the International Carriage of Goods Wholly or Partly by Sea: An Appraisal of the Rotterdam Rules (Springer 2011).

13. See art. 1(2) of the RR.

14. Ibid.

15. See 'Particular Concerns With Regard to the Rotterdam Rules', http://asadip.files.wordpress.com/2010/09/rotterdam-rules-paper-final2_.pdf, accessed 13 March 2015; David Maloof, 'Concerns about Volume Contracts', at http://mlaus.org/archives/library/1904.pdf, accessed 13 March 2015; Hannu Honka, 'Scope of application and freedom of contract', at www.rotterdamrules2009.com/cms/uploads/Def.\%20tekst\%20Hannu\%20Honka.pdf, accessed 13 March 2015.

16. BIMCO is undertaking work to launch its Standard Service Agreement for the liner sector, under the suggested name SERVICECON, see https://www.bimco.org/sitecore/content/home/news/2014/05/09_documentary_committee_meets_in_dubai?RenderSearch=true, accessed 13 March 2015.

17. Art. 35 of the RR.

18. As to the possibility of declaring consent after the volume contract is entered into, see Honka's chapter in von Ziegler, Schelin \& Zunarelli, The Rotterdam Rules 2008 (Kluwer 2010), para. 16.3.6. 
general, or whether he needs to be aware of every individual derogation either. If the former is the case, then there are fewer complications. The issue of concern is how the third party is supposed to consent to something so specific, if article 80(5) of the RR explicitly requests that only the fact of the derogation is known.

Furthermore, article 80(5) may have serious trade dimensions as far as sales on shipment terms are concerned, for various reasons. Frequently in the sale of commodities, the goods are sold afloat several times. The issue here is whether the agreement of the initial shipper and carrier on derogations under a volume contract will be approved of by the third parties/successive buyers of the same goods, in the case of CIF sales down the line. The reasons why a buyer may not like a volume contract concluded outside the scope of the RR are several. This volume contract could be possibly transferring obligations which would normally be for the account of the carrier to the shipper or holder of the transport document. It may also reduce the rights of the third party/holder against the carrier, or contain extensive limitations of liability which can be superimposed against both the shipper and the third party. Especially if a third party buys the goods in order to sell them on, it is in his own interests to check whether these derogations may bring him in breach of his sale contract.

Moreover, this is important in order to know whether a third party can be bound by some of the derogations, if he refuses to consent to others, or lastly whether all the derogations should be accepted or rejected as a whole. Also, the word 'information' is not defined in the article. The vagueness of the article will trigger issues of construction of contracts and incorporation. In this author's opinion, it can be inferred from the article that a sufficient type of notification, and not necessarily the volume contract itself, must be provided to the third party, in written or electronic form. This can be a document which will contain the main terms of carriage, an overall derogating statement and the individual derogations in their substance. These individual derogations must be clearly identifiable.

In this author's opinion, since the aim of article $80(5)$ is to contribute to the better awareness of third parties that the contract of carriage derogates from the norm of the $\mathrm{RR}$, this information should be as full and accurate as possible.

Yet another issue is the time at which a third party receives the information that a volume contract, with derogations, has been entered into. A more specific scenario is the following: a volume contract is concluded and a CIF buyer receives a transport document from his seller. The goods have arrived with a delay, or a shortage, or another type of damage. It is important that the CIF buyer will learn that the carriage contract derogates from the RR after this volume contract has been performed. He will realise his rights at the moment he wants to sue the carrier, and he may find out that, for instance, the carrier has an extremely limited liability towards him. What is the true potential of the consignee's contractual freedom to reject this volume contract, according to article 80(5) of the RR? It is this author's view that the buyer cannot realistically reject at that stage, as it is too late for him to decide to buy the same goods under different carriage terms. Essentially, he would have to choose a different seller who could procure a contract under normal RR's terms, which would now be impossible.

Let us now suppose that the buyer receives both the transport document and the goods at the same time. Although, in theory, the buyer would not otherwise have been willing to accept these derogations from the RR, it is true that if he finds himself in a position where the market is rising, he will be inclined to accept both the transport document evidencing a derogative volume contract and the non-contractual goods, instead of having to buy at a higher price. Consequently, it can be predicted that, practically, there may be cases where third parties are exposed to unpleasant surprises under article 80(5). Moreover, article 80(5) of the RR does not provide an answer to the case of the third party agreeing to be bound by some and not all of the derogations. This author believes that the third party will be bound only by the derogations he has approved of. For this reason, his consent has to be as detailed as possible.

All of the above are also burdensome for an FOB seller, who may be the documentary shipper under the volume contract. Documentary shippers are also third parties for the purposes of article 80(5) of the RR. According to article $1(9)$ of the RR, the documentary shipper is the person that accepts to be named as 'shipper' in the transport document or electronic transport record. Under a straight FOB contract, the buyer enters into the contract of carriage, and hence is the original shipper. If the contract of sale does not specify that the volume contract should not derogate from X, Y or Z obligations, the documentary shipper, as third party to the volume contract may not be willing to accept and be bound by the derogations introduced by the volume contract. This contract, entered into by the buyer qua shipper, may for instance specify that the documentary shipper has more obligations and liabilities than the shipper himself. If the documentary shipper knows the liability standards imposed by the RR on the shipper and documentary shipper, he may want to deny consenting to the derogations agreed by the shipper and carrier.

Nevertheless, the will of the documentary shipper cannot be easily imposed against the contrary opinion of the shipper. For example, under article 35 of the RR, the documentary shipper may request the transport document from the carrier, only if the shipper consents. In light of this remark, the documentary shipper's sole secure method of protecting his interests may be to exhaustively draft his sale contract in a way that prohibits such deviations. Then, a derogatory volume contract will be a breach of the sale contract.

Thus, because of the nebulous drafting of article 80(5) of the RR, the piece of contractual advice that can be advanced is the following: a third party acquiring rights and liabilities under a volume contract needs to pay attention to two elements: a) he should find out all the derogations in detail, and b) if possible, before the contract is performed. Both of these requirements can be safeguarded by explicit terms in the contract of sale, especially if it is concluded prior to the carriage contract.

As for the subsequent third parties (potential buyers down the line), these could be sufficiently informed about derogations through their sale contracts and their coun- 
terparties (seller or buyer). ${ }^{19}$ The sale contracts should preferably contain the acceptable derogations in the form of conditions, so that in case of any breach, the sale contract can be terminated.

Now it is time for another intricacy of article 80(5) of the $\mathrm{RR}$ to be discussed: it has been commented that for the purposes of article 80(5), regardless of whether information on derogation(s) appears in a sale contract, the 'actual derogation' should be included in the transport document or record, so that article $80(2)(\mathrm{d})$ of the RR is satisfied. ${ }^{20}$ This provision states that the derogation should be neither incorporated by reference from another document nor be included in a contract of adhesion which is not subject to negotiation. However, one should not forget that a transport document alone is not a volume contract. ${ }^{21} \mathrm{It}$ has also been clarified that issuance of a transport document is not necessary for the applicability of article 80 of the RR. ${ }^{22}$ Although it can be understood that the transport document is most probably the only document a third party can see, the volume contract itself will most likely be with the original parties. An important issue arises here. Acceptance of the transport document/bill of lading with the statement as to the derogation does not suffice to bind the third party without express consent. ${ }^{23}$ If a transport document/record has not been issued, and the sale contract does not give an indication that the volume contract derogates, then how is the required disclosure/notification of the derogations satisfied in the first place? This means that it should not be taken for granted that the supply contract will necessarily be concluded before the volume contract, or that this contract and the transport document (if issued) will contain a statement that alludes to derogations. These are mere possibilities.

\section{Reflections on the prerequisites for binding a third party to a volume contract: What will the third party receive?}

The enhanced protection intended by the draftsmen of the RR for third parties will need to be examined to verify whether it ensures knowledge by the third party of what he is consenting to. ${ }^{24} \mathrm{It}$ is important at that stage to identify through the existing literature what the third party is likely to receive pursuant to a volume contract. A first issue already identified, ${ }^{25}$ is whether the source of the information as to the derogation of volume contracts will be the sale contract, or the volume contract or anoth- er document: it has been advised that, by signing a sale contract which states that the carriage contract is a volume contract which derogates (and presumably specifies the derogations), traders may validly declare their consent to the derogations. ${ }^{26}$ This is not the only advocated opinion, as in another commentary on the $\mathrm{RR},{ }^{27}$ there is a scenario illustrating that the handing over and acceptance of a transport document which the holder browses through to see its terms and conditions, in the knowledge that it derogates from the RR, are insufficient to prove consent as per article 80(5); this consent needs to be provided in writing too.

Two remarks may be made at this point: that even the commentators themselves may have different expectations as to what a third party will in most circumstances receive as evidence of a volume contract (a supply contract and a transport document, or a volume contract and a transport document). Furthermore, receipt of the volume contract itself or conclusion of the sale contract in sufficient detail in terms of derogations, are both ideal hypothetical scenarios. Article 80(5) does not seem to impose any such obligations either on traders or on the carrier. 'Information' is not defined by the article. This, in this author's opinion, leaves open the possibility of tender of documents with even fewer prerequisites met. And this, in turn, can lead to litigation or at least loss of time, as the third party may exercise pressure or seek additional details before providing consent. Not knowing what has to be submitted to the third party is of great commercial uncertainty. Questions also remain as to the importance of the actual knowledge of the derogations.

\section{Is knowledge necessary?}

It has been submitted that a term to the sale contract such as 'by accepting this document the Merchant is deemed to have given its express consent to be bound by any derogation from the Rotterdam Rules herein contained $^{28} \ldots$ will make the terms fully binding ... whether the parties are aware of the derogatory terms or not' does not protect a third party. ${ }^{29}$ In an illustration from the commentary on the RR by Sturley, Fujita and van der Ziel, it is stated that due to the lack of the formal requirement of consent, the third party is not bound even though he has checked the terms and conditions and intends to accept. $^{30}$ In this author's opinion, the illustrations provided in the above commentaries show the importance of formalities (of the reference to derogations and con-

19. As we shall see, this is a vexing issue, but this author has devised solutions.

20. Comment included in F. Lorenzon, 'Validity of Contractual terms', in: Baatz and others, The Rotterdam Rules: A Practical Annotation, para. 80-10.

21. Art. 80(3) of the RR.

22. See specifically Baatz and others, The Rotterdam Rules: A Practical Annotation, para. 80-07.

23. Sturley, Fujita \& Van der Ziel, The Rotterdam Rules, para. 13.061. See also F. Lorenzon, in: Baatz and others, The Rotterdam Rules: A Practical Annotation, para. 80-10.

24. For the specific contemplation on the vulnerability of third parties, travaux préparatoires of the RR, UNCITRAL Doc A/CN.9/645, paras 237, 241; also see Note by the UNCTAD Secretariat, 'Carrier liability and freedom of contract under the UNCITRAL Draft Instrument on the carriage of goods [wholly or partly] [by sea]', UNCTAD/SDTE/TLB/2004/2, para. 15.

25. Baatz and others, The Rotterdam Rules: A Practical Annotation, para. 80-10.

26. Ibid.

27. Sturley, Fujita \& Van der Ziel, The Rotterdam Rules, Illustration 13-13.

28. See above, Lorenzon, in: Baatz and others, The Rotterdam Rules: A Practical Annotation, para. 80-10.

29. Ibid.

30. Ibid. 
sent) as well as their failure to ensure knowledge of derogations, and consequently protection of the third party. Consent may be provided without actual knowledge. The illustration in the commentary of Sturley and others seems to assume that the third party will make the effort to localise and understand the derogations. ${ }^{31}$ However, it is not clear whether the commentators base this on article 80 or on what was discussed in the negotiations of the Rules. Whether the individual effort of the third party to identify the sections that derogate will depend on how prominent, specific or abstract the information on derogations is, appears to be unclear too.This shows the need for interpretational help, as the vague drafting of article 80(5) of the RR does not seem to explicitly specify this.

In this author's opinion, actual awareness of the derogations, or at least directions as to where they can be found (in full text, and not just figuratively) is not necessary, whereas it should be. This is the rationale of the notification requirement of article 80(5) of the RR. Therefore a narrow-purposive interpretation should be given to Art. $80(5)(a)$. Since this article has been included for the protection of the third party, doubts as to whether a party has knowledge followed by approval of certain derogations, should be resolved in favour of the third party, especially if that party is not a sophisticated one. The above suggestion aims to reduce the possibility of ignorance of a liberty clause or a limitation of liability provision, which would work in favour of the carrier, due to the lack of proper notification of the third party by the shipper or carrier.

Article 80(5) states that the third party 'has received' information on derogation. ${ }^{32}$ In this author's view, this should lead to this interpretation: information as to the derogations has to be furnished by someone and the derogations need to be specifically pointed out, without requiring search initiated by the third party. Article 80(5) does not specify whether all the information has to be provided by someone else, or whether it is the third party's duty to scrutinise the documents that the shipper will make available to him. It seems that one view has been reluctantly expressed through a practical scenario: ${ }^{33}$ 'the holder who received the document noticed the statement, checked the terms and conditions of the volume contract, and received the transport document without objection.' From the wording of the above phrase, it may seem implied that it is the third party's duty to check and therefore identify the derogations.
However, this scenario assumes that the volume contract itself will be tendered to the third party, even though this is not a formal obligation explicitly prescribed by the Convention. Next, this author examines who has to approach the third party to provide him with information and seek consent.

6. Whose responsibility is it to notify the third party of the derogations? Towards a balanced solution

The RR do not explicitly address this obligation. ${ }^{34}$ Some analyses make assumptions, and/or go a bit further in specifying the commercial consequences of this uncertainty. ${ }^{35}$

Requesting express consent is very difficult for a party who is not in some proximity to the shipper or the carrier. ${ }^{36}$ Therefore it is submitted by a renowned commentator that the easiest way of getting consent would be through the shippers' affiliated companies based in other countries. However, it has also been stressed that for the sale of goods already afloat, 'there is no realistic procedure for obtaining the consignee's consent to be bound by the derogations .... ${ }^{37}$ The choice of verbs in the illustration of the commentator discussed above is noteworthy: It is assumed that the document leaves the hands of the shipper and is received $d^{38}$ by a lawful holder who goes through the diverting terms and conditions and receives (this verb is used twice) it without objection.

In any case, the relevant excerpt of the commentary used phrases such as 'it is difficult for the shipper to obtain consent'. Only once is there a phrase saying '... before the carrier can invoke the derogation against any person other than the shipper'. The lack of guidance in article 80 is also criticised by Carver as unnecessarily imprecise, by not saying how and in what form consent should be manifested or evidenced. ${ }^{39}$

Professor Berlingieri ${ }^{40}$ and Diamond $\mathrm{QC}^{41}$ have also dealt with the ambiguities of article 80(5). A point of conflict concerns whether the information must originate from the carrier, or if it is sufficient that it reaches the buyer of the goods from his supplier. It has been asserted that it may be received from any source, so long as it is 'prominent'. ${ }^{42}$

It is important to know who gives information on derogations and who notifies the shipper or carrier of the third party's acceptance or rejection of the derogation. If it can be ascertained who has these obligations, it will be possible to identify who is to be blamed if the information on derogations on the one hand and consent on

31. Sturley, Fujita \& Van der Ziel, The Rotterdam Rules, Illustration 13-13.

32. For a criticism of the verb 'received' used by the draftsmen, see also Sir Guenter Treitel, QC, Francis M.B. Reynolds, QC, Carver on Bills of lading (3rd edn, Sweet \& Maxwell 2011), para. 10-072.

33. See Sturley, Fujita \& Van der Ziel, The Rotterdam Rules, above pp. 382, 383.

34. See Filippo Lorenzon, in: Baatz and others, The Rotterdam Rules: A Practical Annotation, para. 80-10. See also G.H. Treitel, Thomas Gilbert Carver \& Francis M.B. Reynolds, Carver on Bills of lading (3rd edn, Sweet \& Maxwell 2011), para. 10-072.

35. See among others Roberto Bergami, 'Rotterdam Rules: Volume Contracts, Delivery Terms, Transport Documents and Letters of Credit' (2010) 14 (1), The Vindobona Journal of International Commercial Law and Arbitration 9, 19-20.

36. See Sturley, Fujita \& Van der Ziel, The Rotterdam Rules above, para. 13.061.

37. Ibid.

38. This is the exact verb used in the practical example of the commentary which is italicised for emphasis, as it may have repercussions.

39. Ibid.

40. Francesco Berlingieri, 'Revisiting the Rotterdam Rules' (2010) LMCLQ 583, 611.

41. Diamond QC, 'The Rotterdam Rules' (2009) LMCLQ 445, 488.

42. Diamond, 'The Rotterdam Rules', 445, 488. 
the other are communicated wrongly, insufficiently or with delay. Accuracy and commercial certainty are indispensable in international trade.

With regard to whether express consent must be given to the carrier or whether it may be contained in the supply agreement, Diamond states that it is difficult to predict the courts' approach to that, but he is inclined to believe that the provision in article $80(5)$ (b) of the RR may tend to indicate that the consent must be given to the carrier. ${ }^{43}$ In that respect, Berlingieri considers it important to draw a distinction between the contract of carriage and the contract of sale, as usually the purpose for which the contract of carriage is entered into by the shipper is related to the sale of the goods to the consignee. For Berlingieri, the contract to look at is the contract of carriage and the issue is whether the carrier may avail himself of the terms of the contract of carriage that derogate from the Convention agreed with the shipper. ${ }^{44}$ Therefore, he emphasised that consent must become a supplementary term of the contract of carriage and must be received by the carrier. Professor Berlingieri does not reject the possibility that consent reaches the carrier indirectly, but he highlights that ultimately it must be addressed to the carrier. ${ }^{45}$

However, in most cases the particular factual matrix will signify the party able to give the information on derogations and receive the third party's consent.

The above diversity of opinions could seem of little problematic effect where the volume contract is entered into by the shipper who is at first also the consignee, and then decides to sell the goods afloat. This means that the buyer (new consignee) has to consent to the derogations. In that case, the transport document will also be issued and therefore the consent may need to be somehow attached to this document. The problem in that case is that according to article 80(5)(b) of the RR, evidence of consent only through the transport document is not sufficient to bind a third party to the contract. It is also submitted by Carver that article 80(5) RR is there to protect parties who become involved in the volume contracts of others, particularly by taking up transport documents issued under such contracts. ${ }^{46}$ And this is why the identification of the party who sends the acceptance request, and thus, communicates the information on derogations in the first place has to be clarified.

One could argue that this will be the original party to the contract of carriage, namely the shipper or carrier. A narrow/purposive interpretation could be that since the only permanent party in this volume contract is the carrier, whereas third parties may be several, then it is his responsibility to notify any party, other than the shipper, of the derogations. However third parties (eg CIF buyers, FOB documentary shippers, banks etc.) are mostly connected with the shipper (seller or buyer) and not the carrier, by virtue of the underlying sale contract. ${ }^{47}$ The shipper has to ensure that his carriage arrangements are approved by his sale contract counterparty, but the central role of the carrier cannot be disregarded. On the other hand, the carrier is the only person who remains the bill of lading holder's counterparty, regardless of whether the bill of lading holder is a first buyer or a subsequent third party.

Generally, it has been suggested that the document which lists the derogations has to be a contractual document. ${ }^{48}$ This will vary in practice, depending on whether the volume contract had also been concluded or not. If so, then presumably the transport document will be a source of information as long as it is accompanied by additional evidence of communication between shipper and carrier, such as a recap telex. This author has come to this conclusion because of the restriction of article 80(3), which states that a transport document alone is not a volume contract. Although article 80(5) states 'received information' and not 'received the volume contract', for reasons of consistent interpretation of subsections of article 80 , the latter extra requirement has to be implied also in article $80(5)$. This other written or electronic document can be the e-mail, fax or telex, or ideally a counter-acceptance slip where the original shipper and carrier confirm the agreed derogations.

A balanced solution, where both carrier and shipper are responsible for the accurate communication of derogations, is the use of a countersigned acceptance form in order to promote the aim of article 80(5) of the RR. Such a form, as we shall see, can be used for the conclusion of sale contracts. The appropriateness of this solution, in light of case law, will appear under a separate heading below. For now, we are only focusing on how relevant parties should cooperate for purposes of information on derogations and consent.

The form will first be signed by the shipper and carrier and address sufficient vigilance to the derogations, and will subsequently be delivered to the third party by the shipper, or even the carrier. However the opportunity for the carrier to be notified of the acceptance of derogations is preserved, if there is a requirement, under the carriage and sale contracts, to present the second copy of the form, containing the third party's approval or rejection, to the carrier. In case of an FOB contract where the third party is the documentary shipper qua seller, the countersigned acceptance form can be delivered back to the carrier before loading commences, so that the carrier is aware of whether the RR liability regime or the derogations he has negotiated with the shipper will apply. Thus, the derogations can accurately originate from both original parties to the volume contract, without undermining the role of the carrier, or transposing all of this responsibility merely on the shipper's shoulders.

43. Ibid.

44. Berlingieri, 'Revisiting the Rotterdam Rules' 583, 611.

45. Ibid.

46. Carver on Bills of Lading (3rd edn, Sweet \& Maxwell 2011), para. 10-072.

47. For an illustration of how the international trade context affected the drafting of the RR, see Alexander von Ziegler, 'The Rotterdam Rules and the underlying sale contract' at www.comitemaritime.org/Uploads/Rotterdam\%20Rules/Paper\%20of\%20Tomotaka\%20Fujita.pdf, accessed 13 March 2015.

48. See Parker v. South Eastern Railway (1877) 2 C.P.D. 416, below. 
By adopting this device of contract formation which is recognised under common law, ${ }^{49}$ English contract law seems to suggest the optimal way for manifesting or evidencing the third party's consent, which was another ambiguity of article 80(5). However, it needs to be emphasised that it is first and foremost the parties that need to unequivocally stipulate this methodological obligation of exchange of slips in their sale and volume contracts. The clear intention of the parties will clarify whose obligation it is to inform, in which detail, way and at what time. However, this author believes that a form/slip which lists the derogations and produces binding results only with the signature of the third party is a balanced commercial solution. This is the platform for providing information and seeking consent, as we shall see in a subsequent section.

\section{More issues that need to be addressed}

To put everything back into context, article 3 of the RR states that the notices, confirmation, consent, agreement, declaration and other communications relating to a volume contract ${ }^{50}$ need to be in writing. In practice, the furnishing of this information, and also of consent will trigger difficulties. Considering that the RR allow the parties to derogate only from some of their provisions and abide by others (the so-called 'cherry-picking' 51 effect of volume contracts), it seems that it is open to the third party to approve of only one or some derogations. Consequently, if the third party gives a general consent instead of a specific one, then presumably all of the derogations could be validly binding. Even if the third party had specified his approval/rejection of one of the derogations orally, this will not be sufficient to protect him, as the consent has to be in writing. One should not forget the following: a volume contract, or transport document issued pursuant to the volume contract, should prominently specify that it is a volume contract which derogates from the RR, but this may be of very little effect if the volume contract has any general statements of the form: 'This volume contract derogates from the Rotterdam Rules', or 'On 01 March 2015, the undersigned carrier and shipper have exercised their contractual freedom to derogate from the RR in this individually negotiated volume contract: for the terms of this contract see the annex attached'.

Since consent has to be specific, it can also be assumed that a signature of the consignee or the documentary shipper next to an exhaustive list of derogations followed by a declaration of their acceptance is sufficient. Contrast this with a situation where the consignee/documentary shipper has signed a large pack of documents with the list of derogations 'squeezed in' on different pages of the bundle. This is a tricky situation as the third party might have signed without specific knowledge of the derogations. Whether this possible lack of awareness would be sufficient to displace the principle that a signature in a document binds the person signing to its content remains to be seen. An even trickier scenario would arise when the derogations are to be found in different documents, and not just in the one brought to the third party.

In this author's opinion, lack of reference or consent to derogation(s) should be construed strictly as non-approval, so that the mandatory provisions of the RR apply between the third party and the carrier.

The second issue which needs to be identified concerns the documents suitable for embracing volume contract derogations, on which the consent needs to be expressed. This could be the transport document or the volume contract itself, which is the classic example used by the analyses of the RR on the matter. ${ }^{52}$ This would mean that the transport document has to be checked to see whether it can incorporate derogations from the volume contract. ${ }^{53}$ In theory, this information or source of information on derogations could be satisfied through an email, a recap telex, or a written charterparty. Depending on the circumstances, not all of the above contracts can be deemed to be incorporated into a bill of lading. Support for this argument can be derived from two conflicting cases: The Heidberg ${ }^{54}$ and The Epsilon Rosa. ${ }^{55}$

The Heidberg shows that terms in oral agreements cannot be validly incorporated, and therefore they cannot bind holders of bills of lading. What was transferred to the consignee consisted only of the terms which appeared on the face and reverse of the bill of lading; collateral oral terms were not transferred. A bill of lading does not incorporate the terms of a charterparty which, at the date the bill of lading is issued, has not been put in writing. This makes commercial sense, as it is difficult for the transferee of the bill of lading to refer to terms which are not ascertainable in a written contract. ${ }^{56}$ In The Epsilon Rosa, however, the arbitration clause was held incorporated even though it was included in a recap telex, contrary to the holding in The Heidberg. Depending on which case is followed by the courts, an analogy can be drawn: a recap telex/email can or cannot be produced to the third party as sufficient information on derogations. Under English law, general words of incorporation have the effect of incorporating terms which would not be generally known to the party, against whom they are sought to be enforced. The party seeking to enforce the terms must show that they have been fairly and reasonably brought to the other party's attention. ${ }^{57}$

49. See SARL v. Parkinson (1953) 2 Lloyd's Rep. 487 (CA). This case will be analysed in depth in a subsequent section, when evidence of consent is discussed.

50. Art. 80(2) and (5) of the RR.

51. See Asariotis, 'UNCITRAL Draft Convention', 357.

52. Sturley, Fujita \& Van der Ziel, The Rotterdam Rules, in Illustration 13-13.

53. Diamond, 'The Rotterdam Rules', 445, 488-489.

54. The Heidberg (1994) 2 Lloyd's Rep. 287 (QB).

55. Welex A.G. v. Rosa Maritime Limited (2003) 2 Lloyd's Law Rep. 509 (CA).

56. (1994) 2 Lloyd's Rep. 287, 310.

57. Parkerv. South Eastern Railway Co (1877) 2 C.P.D. 416 (CA); Interfoto Picture Library Ltd. v. Stiletto Visual Programmes Ltd. (1989) Q.B. 433 (CA), cited in The Heidberg, at p. 313. 


\section{Significance of the above remarks for buyers/ receivers of the transport documents}

If The Heidberg is followed, the recap telexes of volume contracts which have not been otherwise put in writing will not be capable of incorporation, or to be more accurate, qualify as sources of information or notification of derogations.

The recap telex is usually exchanged at the stage of precontractual negotiations, and the third party becomes part of the volume contract picture after it is concluded and the transport document is transferred to him. However, it is possible for a seller qua shipper to negotiate the volume contract and the sale contract at the same time. It has to be remembered at this stage that according to the RR, consent should not only be registered on the transport document, which at that stage will not have been issued anyway. This is why this author has to investigate what other type of written communication can be used as platform for information. Additionally, it is not clear from the RR whether the consent of the third party needs to co-exist in the volume contract where the carrier's and the shipper's confirmation of derogation(s) will appear. If the answer is negative, then the third party cannot be sure that the derogations are finalised. If this is the case, they have not been properly put in writing in order to be agreed between shipper and carrier; this means that this volume contract is not valid yet and the derogations cannot be properly communicated to the third party either.

The aim of this author is to draw ideas from the complex concept of incorporation, as reflected in The Heidberg and The Epsilon Rosa. These two conflicting cases will make parties particularly vigilant in order to know which document truly reflects a volume contract and is capable of binding third parties on derogations.

Below, this author will attempt to deploy a more certain solution to ensure that parties (carrier and traders) are aware of what derogations are proposed and accepted.

\section{Evidence of consent}

As seen above, the RR do not suggest a prescribed method of registering consent. They only say that consent needs to be in writing or electronic format. This means that, in the lack of further specification from the RR, general commercial and contract law principles will determine the steps which validate the process of binding the third party to some or all of the derogations. Since the fear of all the commentators is that volume contracts will provide the effortless legitimisation of carrier's privileges, the issue of consent deserves special consideration.

It is submitted by this author that, in line with English law, this method could safely materialise through delivery of confirmation slips and completion and dispatch of a countersigned acceptance form. In this author's opinion, this form should contain all of the derogations and the signatures of the original parties to the contract of carriage, namely of carrier and shipper. It has been submitted $^{58}$ that 'where an offer stipulates that acceptance must be by return of an attached form, it being expressly understood that no other form of acceptance will be valid or binding, then unless acceptance is by the prescribed form there will be no contract'. This, in this author's opinion, fits perfectly and fulfils the rationale of article $80(5)$ of the RR, namely that of protection through formal acceptance.

This method is an acknowledged way of contracting in international commercial sales. ${ }^{59}$ The form can be sent in duplicate, so that one is for the CIF buyer's/third party's records, and the other one is to be sent (initially perhaps to the shipper and then to the carrier) to trigger application of article 80(5). Importantly, Schmitthoff ${ }^{60}$ submits that the two acceptance forms which can be drafted (one for the seller and one for the buyer) should tally in their terms, and where appropriate contain a 'red hand clause', i.e. a particularly noticeable statement, which confirms this author's arguments to be analysed later in this article. ${ }^{61}$ It is this author's opinion that volume contracts are a representative example of commercial contracts in international trade that could benefit from utilising the aforementioned contractual devices, in order to satisfy visibility of derogations and guarantee the third party's awareness.

There is already commercial case law on obtaining the offeror's and offeree's written agreement to the terms of a commercial contract: In Compagnie de Commerce et Commission, SARL v. Parkinson Stove Co, ${ }^{62}$ a dispute arose as to whether there was a binding sale contract concluded on FOB terms, between the seller, SARL and the buyer, Parkinson. The order form sent by the seller to the buyer stated the following: ${ }^{63}$

Acceptance. This order constitutes an offer on the part of the First Party upon the terms and conditions and at the prices stated herein and to constitute a binding contract upon the First Party, said offer must be accepted by execution of the acknowledgment in the form attached by Second Party, it being expressly understood that no other form of acceptance, verbal or written, will be valid or binding upon First Party. There are no agreements or understandings other than those contained in this order. This explicitly drafted clause is in this author's opinion the optimal example so that the third party can validly adhere to a volume contract which derogates from the RR. However it was the buyer's non-compliance with the formality of acceptance, which determined that the contract had not been concluded. This case can serve as an effective example of how to evidence consent to derogations from the RR. That could save uncertainty

58. Carole Murrray, David Holloway \& Daren Timson-Hunt (eds.), Schmitthoff: The Law and Practice of International Trade (12th edn, Sweet \& Maxwell 2012), para. 3-010 (hereafter Schmitthoff).

59. Schmitthoff, para. 3-011.

60. Ibid.

61. For this author's submission as to why limitation of liability derogations needs to be conspicuously addressed in a written form to the third party, see below.

62. (1953) 2 Lloyd's Rep. 487.

63. Ibid. 490. 
when the volume contract is unavailable. ${ }^{64}$ At first instance, Pilcher J held that the contract had been concluded as to its general details and therefore the omission of signing and reverting the confirmation slip was immaterial to the formation of the contract. Pilcher $J$ reached that conclusion because of the subsequent exchange of letters between the parties.

Both Singleton LJ and Hodson LJ, in the Court of Appeal, concluded that the form of acceptance prescribed by the contract was not met and therefore a clear acceptance in the terms of the slip was needed but never received; although one party may have thought that the sale contract was concluded, the parties were in fact never ad idem as to the substitution of one form of acceptance for another or indeed as to the terms of the contract; ${ }^{65}$ therefore there was no contract. ${ }^{66}$

Coming back to this author's suggestion, an acceptance form which is also signed by the carrier is an appropriate solution where the transport document has been transferred to a receiver of the goods other than the initial shipper. In a scenario of consecutive sales, the initial shipper will no longer have an interest in the goods, and he will be replaced by the subsequent buyer/holder of the transport document. That way, the role of the carrier is preserved, whereas the initial shipper is logically dismissed, without enhancing the danger that the third party may receive altered or inaccurate information of the derogations.

\section{Why placing proper emphasis on the derogations matters}

This author has recommended specific stages so that proper notification of derogations to third parties can be secured. It is now time to explore an important question: can the third party adhere to all of the derogations by a general consent and can acceptance of a contract that derogates (volume contract) embrace all the derogations that this volume contract contains? This is important if the third party belongs to the category of small/mediumsized shippers who have a weaker negotiating power compared to the carrier. It is for these parties that this author believes that the red-hand rule cases may (or may eventually have to) be 'resurrected' as a mechanism of protection. $^{67}$

Case law on incorporation of exemption clauses or onerous terms is also important as far as volume contracts are concerned. It gives an indication as to how English courts may (or may have to) assess the supply of information, for parties to give their consent: its particular value is with regard to what should be addressed to the third party in order to constitute a sufficient notification of derogations. Although most cases mentioned below are ticket cases between business and consumers, compared to business-to-business transactions in shipping and trade, the analogy is justified when volume contracts are concluded by small and thus, unsophisticated traders.

The cases on the red hand rule ${ }^{68}$ will ensure that the derogations are properly pointed out and thus perused and considered.

English law would impose the following filter on the transferability of exemption of liability clauses: that specific attention has to be drawn to the 'conditions' - the onerous clauses. Possibly, this filter would be of useful application to derogations exempting the carrier from liability, and other onerous or unusual clauses.

It has to be remembered that at certain points, 'usual' and 'reasonable' terms are used as different standards of clauses, leading to different considerations. In the light of Interfoto Picture Library Ltd v. Stiletto Visual Programmes $L t d{ }^{69}$ it has to be examined whether all reasonable steps have been taken to fairly and reasonably bring the derogations (exemptions) to the attention of the third party before requesting consent.

\section{The red hand rule cases}

Although under common law, incorporation of terms can take place in three ways, namely by signature, notice and conduct, the combined reading of articles 3 and 80 of the RR on volume contracts would render incorporation (of derogations) valid against third parties only via notice. The terms should have been contained or referred to in a document which was intended to have contractual effect and reasonable steps must be taken to bring the terms to the attention of the other party.

Before embarking on a review of case law, it has been established by cases that in instances of unsigned documents, the general rule is that the party affected by the clause will be bound if the party tendering the document has done what may be considered sufficient to give notice of the clause to persons of the class in which they belong. ${ }^{70}$

64. However, this author anticipates here that even this form may not be sufficient to hold the parties bound by incorporation if the red-hand rule principle is missing.

65. (1953) 2 Lloyd's Rep. 487, at 502.

66. Birkett LJ dissented, being satisfied that although the acceptance slip was not signed, there was a tacit acceptance of the contract. He agreed with Pilcher J and referred to a specific abstract of Chitty (see (1953) 2 Lloyd's Rep. 487, at 494-495 referring to Chitty on Contracts, 20th edn., p. 143). According to relevant passage from Chitty, 'an agreement ought to receive that construction which its language will admit, which will best effectuate the intention of the parties and that greater regard is to be had to the clear intent of the parties than to any particular words which they may have used in the expression of their intent.'

67. It is recalled that these dangers have been presented with great emphasis by UNCTAD, see Note by the UNCTAD Secretariat, 'Carrier liability and freedom of contract under the UNCITRAL Draft Instrument on the Carriage of Goods [wholly or partly] [by sea]' UNCTAD/SDTE/TLB/2004/2, para. 15.

68. These will be discussed in the subsequent section.

69. (1989) Q.B. 433.

70. See HG Beale (ed.), Chitty on Contracts, Vol I, General Principles (31st edn, Sweet \& Maxwell 2012), para. 14-002, citing Parker v. South Eastern Ry (1877) 2 C.P.D. 416; Richardson, Spence, E Co v. Rowntree (1894) A.C. 217 (HL); Hood v. Anchor Line (Henderson Bros) Ltd (1918) A.C. 837 (HL); McCutcheon v. David Macbrayne Ltd. (1964) 1 W.L.R. 125 (HL); Thornton v. Shoelane Parking Ltd (1971) 2 Q.B. 163; Shepherd Homes Ltd v. Encia Remediation Ltd (2007) EWHC 70 (TCC) (QB). 
In Parker v. South Eastern Railway ${ }^{71}$ the cloakroom ticket contained no specific warning as to the 'conditions' (in their entirety) being addressed to the attention of the passenger, so the issue was whether the customer was bound by the limitation of liability conditions ${ }^{72}$ despite the fact that he had never read them. Mellish LJ held that where an action is brought on a written agreement which is signed by the defendant, the agreement is demonstrated by proving his signature, and, in the absence of fraud, it is wholly immaterial that he has not read the agreement and does not know its contents. 'The parties may, however, reduce their agreement into writing, so that the writing constitutes the sole evidence of the agreement, without having any signature; but in that case there must be evidence independently of the agreement itself to prove that the defendant has assented to it ${ }^{\prime} .^{73}$ The party receiving the ticket is bound by the condition even if unread, if there is reasonably sufficient notice on it pointing out that there are conditions written on the document received. $^{74}$

It was also submitted as obiter by the judge, ${ }^{75}$ that bills of lading are different from tickets or cloakroom vouchers, in that even if not read, any businessman who ships the goods and receives this document should expect that this contains the terms of the contract of carriage. If that obiter dictum applied also to the derogations of volume contracts, it would seem to establish a burden both on the shipper and the third party to examine the terms of the volume contract (and therefore also the derogations) carefully. Accordingly, a noticeable statement that this is a transport document deviating from the RR, would suffice to make the third party bound by the derogations. The notice which has to be shown to the party depends on whether the restriction introduced by the condition 'is not shown to be usual in that class of contract'. ${ }^{76}$

Unlike Parker v. South Railway, in Spurling v. Bradshaw, ${ }^{77}$ the court considered the incorporation of clauses not as a whole, but it considered incorporation of a condition which was particularly onerous independently.

This case established the so-called red hand rule: 'Some clauses ... would need to be printed in red ink on the face of the document with a red hand pointing to it before the notice could be held to be sufficient. ${ }^{, 78}$ The dispute arose with regard to an exemption clause in a warehousing contract. Denning LJ held that the more unreasonable a clause is, the greater the notice which must be given of it. This reminds us of the requirement of articles 80 (2)(a) and $80(5)$ of the RR that the volume contract contains a prominent statement that it derogates from the RR.

Spurling v. Bradshaw is not very enlightening in providing guidance as to which clause may be 'unreasonable', because all judges agreed that the clause had been incorporated. ${ }^{79}$ The red hand rule was further clarified in the Thornton v. Shoe Lane ${ }^{80}$ case, applicable to cases not only of onerous terms, but also of unusual ones. Thornton went one step further than Parker in examining incorporation of particularly onerous exemption conditions and established a reasonableness test that the notification should embrace. This judgment could be useful for assessing whether derogation clauses, incorporated into a bill of lading or other document, satisfy the notification requirement from the perspective of reasonableness. That way it can be ascertained whether the Thornton case could impose restrictions on the impact of holding unreasonable derogations not binding on third parties, although they may be technically accepted.

This case talks about unusual rather than unreasonable terms, unlike Spurling. In Thornton, the entire question was about whether the exemption of liability provision was part of the contract ${ }^{81}$ and the dicta of both Lord Denning and Megaw LJ are important. Lord Denning clarified the application of the red hand rule in that an exclusion clause such as that of the case was 'so wide and destructive of rights that the court should not hold any man bound by it unless it is drawn to his attention in the most explicit way, ${ }^{82}$ He found that no reasonably sufficient notice was given. ${ }^{83}$

Megaw LJ used a different approach: ${ }^{84}$

'Where the particular condition relied on involves a sort of restriction that is not usual in that class of contract, a defendant must show that his intention to attach an unusual condition of that particular nature was fairly brought to the notice of the other party. How much is required depends upon the restrictive condition.'

Megaw LJ endorsed Lord Dunedin's test in Hood v. Anchor. ${ }^{85}$

All of the above cases were considered in the case Interfoto Picture Library Ltd v. Stiletto Visual Programmes $L t d{ }^{86}$ The dispute arose with regard to the application of a clause initiating an unusual and outrageous holding

71. (1877) 2 C.P.D. 416

72. The judgment just refers to conditions without further qualifying whether they are exemption or limitation of liability clauses.

73. (1877) 2 C.P.D. $416,421$.

74. (1877) 2 C.P.D. 416, 423. See also E. Macdonald, 'The duty to give notice of unusual contract terms' (1988) JBL 375, 379

75. (1877) 2 C.P.D. $416,422$.

76. Ibid. 424. This case was considered in Interfoto $v$. Stiletto.

77. (1956) 1 W.L.R. 461 (CA).

78. Ibid. 466, per Denning LJ. Contrast this with Hood v. Anchor Line (Henderson Bros.) Ltd. (1918) A.C. 837.

79. See below E. Macdonald, 'The duty to give notice of unusual contract terms' (1988) JBL 375, 376.

80. (1971) 2 Q.B. 163 (CA).

81. As Lord Denning M.R. highlighted at (1971) 2 Q.B. 163, at 170.

82. Ibid. 170 .

83. Ibid.

84. Ibid. 172 .

85. Hood v. Anchor Line (Henderson Brothers) Ltd. (1918) A.C. 837, at 846, 847 (per Lord Dunedin): 'Accordingly it is in each case a question of circumstance whether the sort of restriction that is expressed in any writing (which, of course, includes printed matter) is a thing that is usual, and whether, being usual, it has been fairly brought before the notice of the accepting party.'

86. (1989) Q.B. 433. 
fee for late delivery in returning photographic transparencies to the plaintiffs. The appellants had delivered the transparencies to the respondents along with a delivery note containing nine conditions. The crucial condition concerned the inflated holding fee. On appeal, the court held that where clauses incorporated into a contract contained a particularly onerous or unusual condition, the party seeking to enforce that condition had to show that it had been brought fairly and reasonably to the attention of the third party. The Thornton case was approved therein, especially with regard to exemption clauses which would deprive the party, on whom imposed, of his statutory rights. ${ }^{87}$ This is remarkably analogous to the potential derogations from the RR, as they are expected to concern exemption of liability provisions favourable to the carrier rendering the regular provisions of the RR inapplicable.

If the red-hand rule is applied to derogations on volume contracts, mere or defective reference to derogations on the transport document or to a list of terms attached will not be capable of incorporation unless there is specific attention pointed to them, and to the extent that courts do not find them unreasonable. ${ }^{88}$

These cases and especially Interfoto Picture Library Ltd v. Stiletto Visual Programmes Ltd would add more comprehensive steps for the fulfilment of the conditions of article 80(5) RR especially with regard to derogations not sufficiently pointed out. Volume contracts offer an exceptional opportunity for the red-hand rule to come into play and to be further defined in commercial cases. More concretely, if a purposive interpretation which embraces the red-hand rule applied, this would mean that the notifying party should not only warn that it is a volume contract, but also designate the derogations one by one. A scenario where the shipper just tenders a bill of lading (with a covering sheet followed by annex of the terms of the volume contract) saying 'this is a contract which may derogate from the RR, would not be sufficient to validate the consent given, if there is no proper presentation of the individual derogations, or the third party is not directed to them. The situation would be different and the original parties to a volume contract would be released from the need to act further if they furnished one document which clearly stated the provisions which derogated from the RR, notably if all the derogations were listed at the beginning of the document before any other contractual terms.

\section{Concluding Remarks}

The possibility of displacing the mandatory scope of the Rotterdam Rules through the device of volume contracts has been received with great scepticism by states and the industry. It has to be recalled that volume contracts allow derogations from the RR, which under certain conditions may extend to third parties.

The concept of volume contracts has been examined from the perspective of third parties so as to shed light on whether the scepticism towards volume contracts is justified. This contribution has aimed to decrypt article $80(5)$ of the RR and demonstrate a way of binding a third party to a volume contract which derogates from the RR. Information on derogations, parties in charge, timing and forms for requesting and receiving consent to derogations have been discussed with suggestions for all the parties to the trade chain involved. The overall purpose of this contribution has been to identify the ambiguities behind the relevant articles of the Rotterdam Rules and give them interpretational help. Purposive interpretation of art. 80(5) and solutions which are in line with the travaux préparatoires and enhance commercial certainty have been devised by this author.

Furthermore, this contribution demonstrated the steps that third parties should take to enter into or validly reject derogations contained in the customised carriage agreements, the so-called volume contracts.

The originality of this contribution lies in that it is the first analysis of this article of the RR in terms of third parties being bound by volume contracts with derogations. This contribution has gone beyond the hesitation of the existing literature to introduce the judicial and contractual measures that will have to be activated in order to give third parties a valid freedom of choice.

It has been underlined that the rationale of allowing customised agreements to derogate from the RR when parties are equally sophisticated is missing. Thus, nothing precludes the possibility of volume contracts becoming a technical device, so that more and more contracts can be eligible for derogation. This contribution has attempted to highlight the substance of these concerns especially for third parties who have not negotiated the derogations, highlighting the vagueness of article 80(5) of the RR. Identification of the party to the carriage contract in charge of communicating the derogations and drawing consent was a vexing issue identified by this author. This author has suggested that a volume contract has to be followed by a slip listing the derogations by substance and section, signed by shipper and carrier initially, and then transferred to any subsequent third party, while a record of this acceptance remains with the carrier. However, this is a contractual option; therefore, the sale contract and the volume contract have to specifically stipulate that derogations should be communicated through that slip, so that the relevant parties sign it.

If the parties have not been sufficiently proactive in this regard, and especially when the goods are sold afloat to subsequent buyers, then English law protection cases and especially the red hand rule cases might have to be revived in order to hold that onerous clauses or unreasonable terms have to be pointed out in a particularly noticeable way. This will require the notifying party to specifically point out which are the derogating sections and where they are contained, especially if they exist in several documents. This will enable the party to peruse the terms, so that they are consciously read and then approved or rejected. Exclusion of the carrier's liability could fall under this description of terms, but article 80(5) of the RR fails to explicitly introduce a similar comprehensive set

87. Ibid. 438.

88. For the red hand rule test in commercial cases, see also Melis Ozdel, 'Incorporation of charterparty clauses into Bills of Lading', in: M. Clarke (ed.), Maritime Law Evolving (Hart Publishing 2013) 181, 188-190. 
of requirements to ensure acceptance of derogations by the third party.

The occurrence of the fears illustrated in this contribution, which were also persistently highlighted by UNCTAD, would be diminished if the safeguards discussed above were imposed by courts, when such disputes arise. Alternatively, it would be more reassuring to have an overseeing international authority, like the Federal Maritime Commission, in terms of service contracts in the USA, ${ }^{89}$ to supervise whether volume contracts with derogations are actually individually and independently negotiated and agreed upon by original and third parties. Nevertheless, one should not underestimate the power of careful and thorough contract drafting; therefore, the eradication of the undesirable contingencies discussed could ideally be promoted by traders themselves.

It has been underlined by this author that the red hand rule only ostensibly permeates article 80 of the RR, but not to a great extent. This means that the general fact of the derogation has to be particularly noticeable, but article $80(5)$ is not detailed as to how the individual derogations should be put in writing and whether they should appear in a certain document. This is why this author insists that clearly and prominently documented derogations, and offer and acceptance of these through slips, would ensure that all commercial parties (the carrier included) are aware of the process of acceptance. This suggestion takes into consideration that carriage under an already concluded volume contract may involve more traders, other than the original seller and buyer, if the goods are sold down the line.

It has been submitted that volume contract derogations may be accepted through technical requirements, without knowledge being guaranteed. It has also been commented that the RR do not specify who is responsible for furnishing information on derogations and drawing consent and at what point in time. This author has suggested for the first time how this can be rectified and has also ensured that all relevant parties have a role in approaching third parties and ensuring that consent or rejection reaches the carrier. The solutions are balanced and appropriate after an interpretation of article 80(5) in light of its principles. It is in the interest of legal certainty that article 80(5) of the RR serves for the protection of third parties, especially of the less sophisticated parties.

Overall, in order to preserve the legal and also commercial viability of derogations from the Rotterdam Rules without unpleasant surprises, information on what volume contract derogations may entail and how they should be communicated will become of immense commercial value as far as third parties to volume contracts are concerned. 